CURRENT RESEARCH JOURNAL OF HISTORY

(ISSN -2767-472X)

VOLUME 03 ISSUE 01 Pages: 40-43

SJIF IMPACT FACTOR (2021: 5. 505)

OCLC - 1243560778 METADATA IF - 6.458

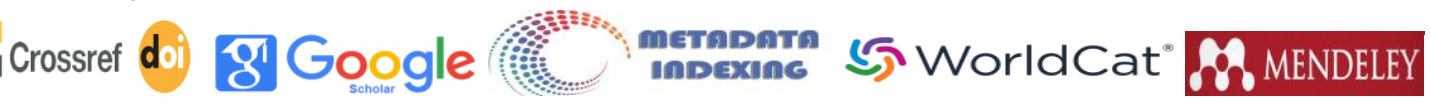

Publisher: Master Journals

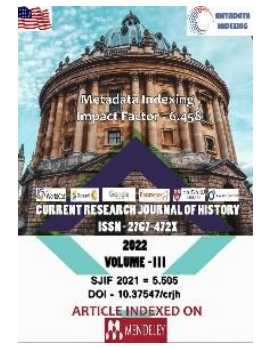

Journal Website: https://masterjournals. com/index.php/crjh

Copyright: Original content from this work may be used under the terms of the creative commons attributes 4.0 licence.
Research Article

\section{HISTORICAL ROOTS OF THE ENERGY INDUSTRY IN UZBEKISTAN}

Submission Date: January 11, 2022, Accepted Date: January 21, 2022, Published Date: January 31, 2022

Crossref doi: https://doi.org/10.37547/history-crih-03-01-09

Shoira Khakimova

Researcher National University of Uzbekistan Tashkent, Uzbekistan

\title{
ABSTRACT
}

The power industry has a huge impact on the development of electrification systems. This article provides information on the construction of hydropower plants in Uzbekistan, the establishment of electricity generation and power sources, electrification of the country.

KEYWORDS

Electric power industry, hydroelectric power station, electric sources, power station, fuel energy industry.

\section{INTRODUCTION}

The use of electricity in industry, transport and agriculture for domestic and cultural purposes is called electrification. Electrification is a leading factor in the development of all sectors of the economy, the realization of modern development.

THE MAIN RESULTS AND FINDINGS
The history of electricity generation in Uzbekistan and its use in various sectors of the economy dates back to the beginning of the last century. Under the colonial rule of the Russian Empire, two power stations were first built in Tashkent in the early twentieth century. In 1913, the total capacity of the 
CURRENT RESEARCH JOURNAL OF HISTORY

(ISSN -2767-472X)

VOLUME 03 ISSUE 01 Pages: 40-43

SJIF IMPACT FACTOR (2021: 5. 505)

OCLC - 1243560778 METADATA IF - 6.458

Crossref do
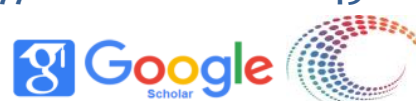

metapata

5) WorldCat" भి MENDELEY

Publisher: Master Journals

Turkestan region was $3 \mathrm{~kW}$. There are 6 diesel power plants with an annual capacity of 3.3 million. kW. was equal to $[1,3 \mathrm{p}]$.

In 1913, the total capacity of power plants in Russia was 1.1 million $\mathrm{kWh}$, and electricity generation was 2 billion $\mathrm{kWh}$. Electrification developed rapidly after the adoption of the GOELRO plan in 1920, and by the mid1960s, the former Soviet Union was the world's second largest (after the United States) in terms of electricity generation.

Construction of hydropower plants in Uzbekistan began in 1923 with the construction of Bozsuv HPP in Tashkent. HPP was launched on May 1, 1926 and thus laid the foundation of the energy system of Uzbekistan [7, p. 76]. At that time, the Bozsuv HPP was the first and largest power plant in Central Asia. HPP has played an important role in providing industrial enterprises, urban transport and electricity to the population of Tashkent.

1926 - is characterized by further development of energy in Uzbekistan. Uninterrupted supply of electricity to the textile industry and other types of industrial enterprises will be ensured. Kerosene lighting at night on city streets will be eliminated.

Before and after the Second World War, Kadyriya, Borijar in 1936, Tavaksay in 1941, Ak-Qaboq in 1946, Khishrav in 1956, Charvak in 1971-1972, and Khojakent HPPs were built and put into operation in Uzbekistan in 1933 [7, pp. 76-82. ]. The construction and commissioning of large hydropower plants has led to an increase in water resources in the country's electricity balance, and as a result, the reservoirs created as a result of their construction have allowed to irrigate new lands.
In April 1932, a decision was made to build a two-stage hydroelectric power plant and a nitrogen fertilizer plant in the Chirchik River Valley. At the same time, a state administration called Chirchikstroy will be established. In 1934, it was transformed into the State Union Construction and Assembly Trust. In 1951, Sredazgidroenergostroy was reorganized in 1957 into Uzbekhydroenergostroy. This trust is building hydro, thermal power plants, canals and reservoirs, cities and workers' fortresses under the name of JSC "Uzbekhydroenergomaxsusqurilish" [2, p. 58]. In the twentieth century, Uzbekistan has developed more diversified machinery, chemical, oil, coal, gas, mining, gold mining, and especially energy industries than the light and food industries. In addition, a number of measures have been taken to generate electricity, which is necessary for the development of these industries. In particular, in the 60-80 of the last century in Uzbekistan Angren, Navoi, Charvak, Tashkent and other large power plants were built and put into operation [9, p. 522]. The Chirchik-Bozsuv cascade of hydropower plants with a total capacity of more than 300,000 kW was also restored. The Syrdarya GRES, the largest in Central Asia with a capacity of 3 million $\mathrm{kW}$, has been built. As a result, electricity production in the republic in 1985 increased almost 180 times compared to 1940 [5, p. 47].

In 1990, the total capacity of power plants exceeded 350 million $\mathrm{kWh}$ and generated about 2 trillion $\mathrm{kWh}$ of electricity per year.

In the field of fuel and energy, which is an integral part of the energy system, a lot of work has been done during this period. In particular, the fuel industry, which includes the extraction of natural gas, oil, coal, oil refining and delivery of finished products to consumers, has become one of the most important sectors of the country's heavy industry. As one of the 
CURRENT RESEARCH JOURNAL OF HISTORY

(ISSN -2767-472X)

VOLUME 03 ISSUE 01 Pages: 40-43

SJIF IMPACT FACTOR (2021: 5. 505)

OCLC - 1243560778 METADATA IF - 6.458

Crossref do

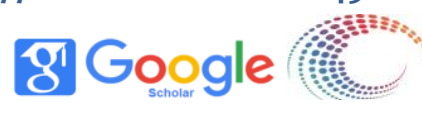

metดDคTต

indexune

5) WorldCat" भ̂े MENDELEY

Publisher: Master Journals

most important sectors of the fuel and energy industry is the gas industry, a lot of attention has been paid to this sector.

Thanks to the hard work of the Uzbek people, a large and powerful gas industry complex was created in the republic in 1946-1985. Major gas fields such as Jarkoq, Gazli, Uchkir, Saritosh, Mubarek, Shurtan, Ortabulak, Yangi Kazgan were discovered and put into operation. As a result, in 1940, Uzbekistan produced 0.7 billion cubic meters of gas, compared to 22 billion 566 million cubic meters in 1966 [4, 112 p], in 1970 - 32.1 billion, in $1980-34.8$ billion [6,53 p] and in 1986 amounted to 38.6 billion cubic meters. This has led to a sharp increase in the share of gas in the fuel system of Uzbekistan. As a result, the share of gas consumption in the fuel system in 1960 was 8.6 percent, in 1970 the figure was 64.6 percent, in 198079.6 percent, and in 198580.2 percent.

Also, in 1963 the Bukhara-Ural gas pipeline was launched, and in 1967 the longest Central Asia-Central Asia gas pipeline was put into operation. In 1969, 28 billion cubic meters of water were transported from Uzbekistan to Russia through these two pipelines. cubic meters of natural gas.

During this period, the growth of natural gas production in the country was associated with the discovery and development of large gas fields in the Bukhara-Khiva geological region. The largest gas fields in the country were Gazli, Ortabulak, Uchkir, Jarkoq. Industrial gas production began in the $50 \mathrm{~s}$ and $60 \mathrm{~s}$, and the main centers of this industry were Bukhara and Kashkadarya regions. Gas was also extracted from Fergana and Surkhandarya regions. Since 1970, gas has been used in all major heating power plants (except Angren and Fergana) [10, p. 182]. Before independence, $75 \%$ of natural gas was exported from the country, and after independence, the bulk of it was used to supply domestic areas, their own production facilities.

One of the most important areas of the fuel energy system is undoubtedly the oil industry. The oil industry is the most efficient type of fuel industry today.

The first oil field in Uzbekistan was discovered in 1904 in Fergana. In 1913, 13,000 tons of oil were extracted on the territory of Uzbekistan, while during the First World War, 119,000 tons of oil were extracted [3, p. 70]. During and after the Second World War, new oil fields were put into operation in the Fergana Valley (Southern Olamushuk, Polvontash Andijan) and Southern Uzbekistan (Khaudak, Lalmikor) and the Fergana Oil Refinery was built. However, the production capacity of both plants was low, and the demand for oil products was met by imports.

Under Soviet rule, coal, which had considerable reserves in the fuel and energy complex, played a very important role. The first coal mining in the country began in the late 1930s, in recent years in the Ahangaron valley of Tashkent region, Angren, Sariosiya and Boysun districts of Surkhandarya region. Due to the fact that the country's economy has always been in great demand for coal, large quantities of coal were mined from major coal deposits such as Angren in Tashkent region, Shargun and Boysun in Surkhandarya region. Among them, the Angren brown coal deposit occupies a significant place. It is mined in the open. Therefore, its cost was considered cheap.

Another important aspect of the Angren coal mine was that it was possible to organize the production of ceramics, refractories and other products on the basis of tens of millions of tons of kaolin clays in its waste layers. The quality of coal from the Shargun and Boysun coalfields, which are the main deposits of the 
CURRENT RESEARCH JOURNAL OF HISTORY

(ISSN -2767-472X)

VOLUME 03 ISSUE 01 Pages: 40-43

SJIF IMPACT FACTOR (2021: 5. 505)

OCLC - 1243560778 METADATA IF - 6.458
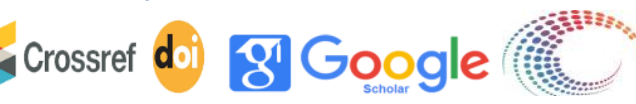

metดDath

5. WorldCat" fô MENDELEY

Publisher: Master Journals

coal industry in the country, was quite good, but the reserves were not very large.

During the Soviet era, coal production in the Republic grew from year to year. In particular, 3.4 thousand tons of coal were mined in 1940, 3.7 million tons in 1970, 5.7 million tons in 1980, and 6.5 million tons in 1990 [3, p. 71]. The mined coal was mainly used as a fuel and partly in the production of electricity. In addition, coal in Angren was converted to underground gas and used to generate electricity at thermal power plants. This underground gas station produces more than 800 million cubic meters of gas a year.

\section{CONCLUSION}

In conclusion, it can be said that electrification is a leading factor in the development of all sectors of the economy, the realization of modern development. During a quarter of a century of development, our country has achieved energy independence, and Uzbekistan has become a country with high energy potential in Central Asia. In the process, a single power system was created, which ensures the parallel and synchronous operation of all power plants, with the ability to supply and export electricity to consumers, regardless of location. At the heart of this work is the reforms carried out in the electricity industry of our country during the former Soviet Union.

\section{REFERENCES}

1. Alimboev A.U., Alimov X.O., Ahmedov K.X. Thermal power plants. - Tashkent: Cholpon Publishing House, 2007.161 p.

2. Akramjonov J., Usmanov R., Irkaev A. Lower Bozsuv HPP cascade: yesterday and today // “Uzbekhydroenergetika”. 2019. №2. - P. 76.
3. Asanov G, Nabihanov $M$ and others. Economic and social geography of Uzbekistan. Tashkent. "Teacher." 1994. s-70

4. Jurakulov O. Powerful energy source. -T.Teacher, 1982, p.112.

5. Narodnoe khozyaystvo Uzbekskoy SSR v 1984 godu. S.47.

6. Narodnoe khozyaystvo Uzbekskoy SSR v 1987 g. I Statisticheskiy ejegodnik /.- T .: Uzbekistan, 1988, 53-bet.

7. Samedjanov A. Anniversaries of hydropower capacities of Uzbekistan // “Uzbekhydroenergetika”. 2021. №1. - P. 76.

8. 3. To'raev B, To'raev Z. History of development of hydroelectric power stations in Uzbekistan. // “Uzbekhydroenergetika”. 2020. №4. - P. 68.

9. Uzbekistan during the Soviet era. 2 books. B.522

10. Encyclopedia UzSSr. s-182 